Ireneusz Malik*, Małgorzata Wistuba*, Agnieszka Czajka*, Katarzyna Łuszczyńska*, Stanisław Czaja*

\title{
The destruction of natural river reaches due to improper land development - an example of the valleys of Czadeczka and Krężelka rivers (Beskid Śląski Mts) ${ }^{1}$
}

\author{
Niszczenie naturalnych odcinków koryt rzecznych \\ na skutek niewłaściwej zabudowy - przykład dolin \\ Czadeczki i Krężelki (Beskid Śląski)
}

\begin{abstract}
*Prof. dr hab. Ireneusz Malik, phone:+48 608588 961, dr Małgorzata Wistuba, drAgnieszka Czajka, lic. Katarzyna Łuszczyńska prof. drhab. Stanisław Czaja, Faculty of Earth Sciences, University of Silesia, Bedzińska 60 Str, 41-200 Sosnowiec, Poland, e-mail: irekgeo@wp.pl
\end{abstract}

Keywords: spatial planning, river valleys, river channel regulation, building development, mountain rivers, Beskid Śląski Mts Słowa kluczowe: planowanie przestrzenne, doliny rzeczne, regulacja koryt rzecznych, zabudowa, rzeki górskie, Beskid Śląski

\section{Abstract}

Channels of Czadeczka and Krężelka rivers (Beskidzie Śląski $\mathrm{Mts}$ ) are at present subjected to regulation because of which these rivers have lost their natural character, partially still preserved. The reasons for the river regulation have been analysed. Using archival maps, the buildings erection time has been analysed on valley floors, in the immediate vicinity of river channels for the period 1790-2012. Next, the distribution of existing buildings has been compared with hydraulic structures in the channels developed in order to regulate the Czadeczka and the Krężelka reaches, such as: concrete and stone embankments reinforcing the channel banks, check dams on channel bottoms. Results indicate a strong correlation between the number of buildings on valley floors in the $20^{\text {th }}$ century and channel regulation. The mechanism of destroying rare, preserved natural river reaches is based on irrational permission allowing construction of buildings in areas threatened by floods and lateral erosion of rivers. Consequently, the inhabitants, in fear of floods and erosion of land or house foundations, seek river regulation that gives them a false sense of security. Natural river reaches are destroyed though efficient protection against floods and lateral erosion is still not provided and the range of possible losses increases even more due to continued building erection.

๑) IOŚ-PIB

\section{INTRODUCTION}

There is strong relationship observed between the way of landuse changing, urbanisation and channel condition [Wolman 1967]. Human effects on mountain streams may result in alteration of channel geometry, the dynamics of water and sediment movement, water contamination, or aquatic and riparian ecosystem [Wohl 2006]. During the last two centuries, the channels response to various types of human activities is being noticed. The main human interventions are river channel training, gravel mining and land-use change [Klimek 1983]. In Polish Carpathians, braided channels typical of the 19th-century rivers [Klimek and Trafas 1972, Wyżga 1993] were progressively

\section{Streszczenie}

Koryta rzek Czadeczki i Krężelki (Beskidzie Śląski) są współcześnie miejscami poddawane regulacji, przez co rzeki te tracą swój naturalny charakter, częściowo nadal zachowany. Przeanalizowano powody dla których rzeki te sa regulowane. Z wykorzystaniem archiwalnych map prześledzono czas powstania budynków w dnach dolin, w bezpośrednim sąsiedztwie koryt rzecznych w latach 1790-2012. Następnie porównano miejsca zabudowane z miejscami występowania elementów regulacji koryt rzecznych takich jak: opaski betonowe wzmacniające brzegi, obudowy kamienne wzmacniające brzegi, progi w dnach koryt. Wyniki wskazują na ścisły związek pomiędzy wzrostem ilości budynków w dnach dolin w XX wieku oraz regulacją koryt. Mechanizm niszczenia nielicznych zachowanych naturalnych odcinków rzek polega na irracjonalnym wydawaniu pozwoleń na zabudowę terenów zalewowych i zagrożonych erozją boczną cieków. Następnie mieszkańcy w obawie przed powodziami i podmywaniem gruntów czy zabudowań zabiegają o regulację cieków, co daje im pozorne poczucie bezpieczeństwa. W efekcie naturalne biegi rzek są niszczone, skuteczna ochrona przeciwpowodziowa i przeciwerozyjna nadal nie jest zapewniona, a skala potencjalnych strat nawet wzrasta ze względu na rozwijającą się zabudowę. 
Most of the training works focussed on altering the nature of the river channels seem to be as ineffective as useless.

Numerous rivers are lately subjects of revitalisation and restoration. To revitalise is to reintroduce ecological functions of a river (e.g. through improving the quality of polluted water) without any technical actions, bringing back the natural character of the channels, banks or valleys. On the other hand, to restore is to return a formerly regulated river to a state close to the natural one (preceding its regulation) [Żelazo 2006]. The need for revitalisation and restoration usually comes from adverse effects of earlier activities conducted in river channels or valleys [Nachlik 2004]. In the strongly developed area of the Beskid Śląski Mts, majority of rivers are regulated, particularly in the built-up areas. Regulations concerned mainly the middle and the lower (outlet) reaches of rivers [Bucała, Radecki-Pawlik 2011]. River channels were straightened, their banks and bottoms were reinforced and dammed with check dams.

In the Beskid Śląski Mts, there are still some river sections with natural channels. Due to spontaneous urbanisation and building development, they are rare in middle and lower reaches of rivers, so those that were preserved are particularly valuable [Krzyk 2010]. Concern with rational development of unregulated river valleys should be a major factor in spatial planning. According to reports by the Polish Supreme Audit Office (in Polish: Najwyższa Izba Kontroli), valley floors and floodplains in Poland have lately been subjects of intense building development [Najwyższa Izba Kontroli 2009]. An increase in building network density is in fact the main reason for growing losses caused by floods [Żbikowski, Żelazo 1993]. When valleys of unregulated rivers are built-up, the channel sections near the new houses are treated with diverse anti-erosion and flood-control actions. As a consequence, the rivers gradually lose their natural courses, yet efficient protection against floods has still not been provided. In addition, river regulation prevents the retention of flood waters in the mountains, which, in turn, causes increased flooding of submontane areas [Bojarski et al. 2005].

In the valleys of the Czadeczka and Krężelka rivers stand some buildings. Several sections of both rivers have natural channels, some sections are reinforced or regulated, also channelised with, for example, check dams and concrete embankments. New buildings have lately been constructed in both valleys. In 2014, construction of bank reinforcements against lateral erosion was also observed. Building development on valley floors of the studied rivers seems to be closely linked to gradual human-induced transformation of the Czadeczka and Krężelka channels, resulting in a false sense of security among the local inhabitants in case of a flood. The aim of the study is to demonstrate the negative impact of the improper development of the valley floors resulting in a destruction of natural river courses in mountain areas as illustrated by the example of the Beskid Śląski Mts.

\section{MATERIALS AND METHODS}

Study was conducted in the Polish part of Czadeczka river basin $\left(23.43 \mathrm{~km}^{2}\right.$ ) located in Beskid Śląski Mts (Kondracki 2000). Czadeczka with its biggest tributary Krężelka river belongs to the
Black Sea Basin. The Polish section of the Czadeczka river is $7.5 \mathrm{~km}$ long, while the length of Krężelka river is $6.6 \mathrm{~km}$.

Using maps of different age, we have analysed the time when buildings were constructed on valley floors of the Czadeczka and Krężelka rivers. We have analysed maps developed in 1790 , 1876, (Austro-Hungarian archival maps of the: Josephinische Landesaufnahme - the $1^{\text {st }}$ military maps published in 1780-83 $1: 28,800$ and Franzisco-Josephinische Landesaufnahme - the $3^{\text {rd }}$ military maps published in 1874-80 1:25,000) and maps developed in 1975, 2012 (Polish topographical maps). In summer-autumn 2014, we conducted a field mapping in the Czadeczka and Krężelka valleys. We mapped diverse effects of human interference into the channel morphology: stone bank reinforcements, concrete embankments, check dams. Next, we compared the distribution of the types of channel regulations with the distribution of buildings on valley floor. We only considered buildings located on terrace levels, without those constructed on outlet fans of the tributaries or those constructed at the foot of the slopes. The valley floors were divided into $500 \mathrm{~m}$ long sections. For each section, we marked and counted the number of buildings, the length of the regulated channel with concrete/ stone embankments, and the number of check dams, based on maps and field survey.

\section{RESULTS AND DISCUSSION}

On the 1790 map, no buildings were found on the valley floors of the Czadeczka and Krężelka rivers. The analysis of a map from 1876 revealed that between 1790 and 1876, five buildings were constructed on valley floors (Fig. 1). Significant settlement of the studied valley floors occurred in 1876-1975. At this time, as many as 72 buildings were constructed on the studied valley floors, 54 of which were in the Czadeczka valley and 18 in the Krężelka valley. On the other hand, from the 2012 map, it is clear that since 1975, 35 more buildings were constructed on the valley floors of the studied rivers. During these 37 years, buildings were constructed mainly in areas formerly inhabited and developed (Fig. 1). Conducted analysis suggests that buildings on the valley floors of the Czadeczka and Krężelka were constructed mainly in the $20^{\text {th }}$ century. The upper river reaches remained uninhabited. Houses were built in the middle and the lower sections of the valleys. Concrete and stone embankments are found along 780 $\mathrm{m}$ of the Czadeczka channel and $360 \mathrm{~m}$ of the Krężelka channel (Fig. 2). In the channel of the Czadeczka river, more check dams were found (25) than those found in the channel of Krężelka river (4 only) (Figs. 2, 3). Most of the artificial hydraulic structures were found in the Czadeczka valley. Check dams and concrete/ stone embankments were found near building locations. This is particularly clear in the Czadeczka valley. In case of the Krężelka river, buildings are more dispersed along the valley floor. Check dams were found only in the outlet section of the channel. It is, however, clear that the components of channel regulation were found mostly in the areas where buildings were located.

The process of channel regulation and reinforcement is still being continued in the study area. In October 2014, we observed works conducted to prevent lateral erosion in the Krężelka channel. A stone embankment was constructed close to the area where a 


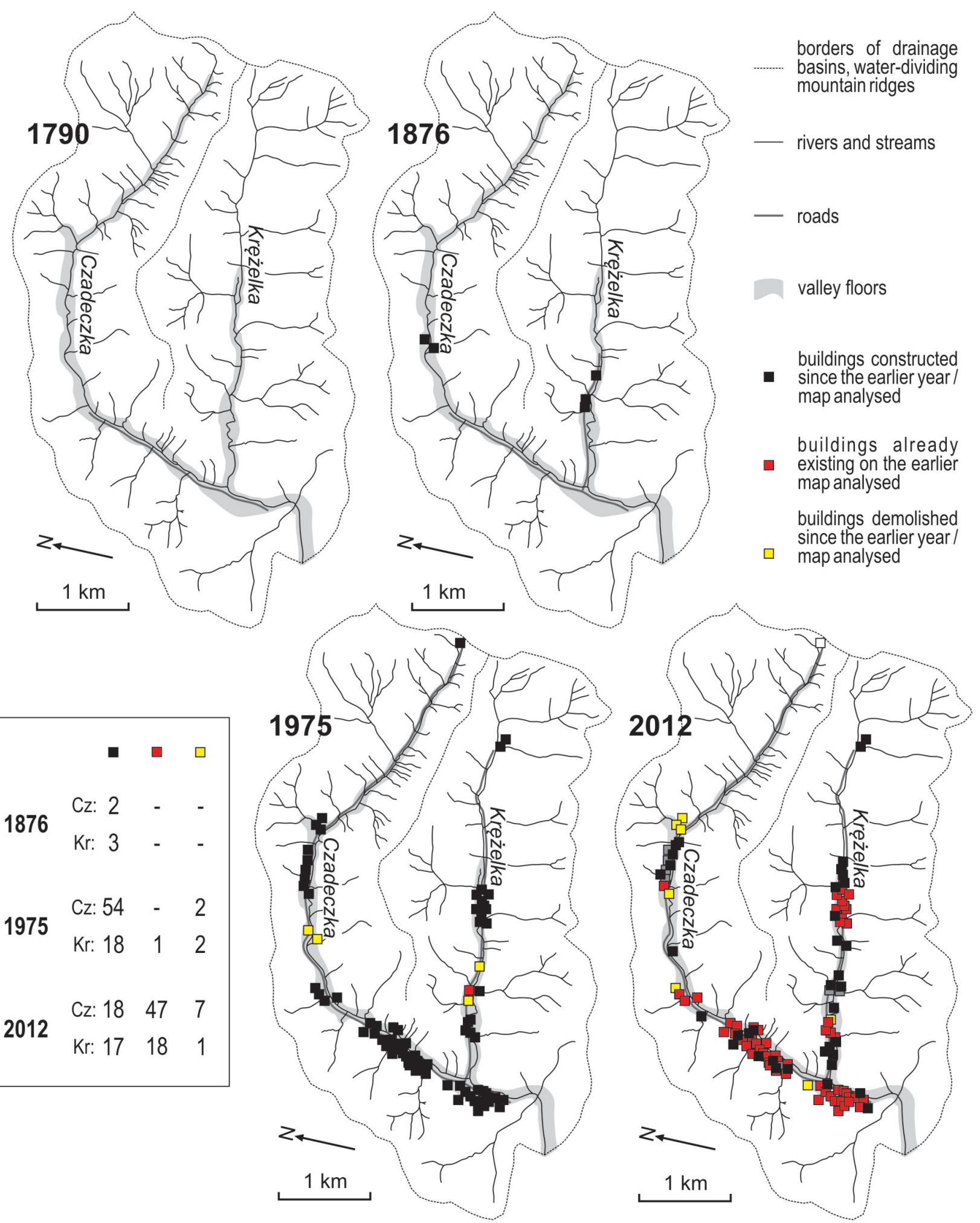

Fig. 1. Changes in the number of buildings located on the valley floors of the Czadeczka and the Krężelka (based on the analysis of maps from 1790, 1876, 1975, and 2012).

house was going to be built (Fig. 4). Furthermore, gradual building development of the valleys will cause further regulation of the river channels. Results achieved indicate that the destruction of the natural river reaches results from the issuance of construction permits in the area of the Czadeczka and Krężelka valley floors despite the risk of flooding and erosion. The owners of the houses located on the valley floor demand river regulation due to fear of lateral erosion of sinuous channels that can undercut building foundations. During the field survey, we met with numerous requests for regulating the Czadeczka and Krężelka channels. 

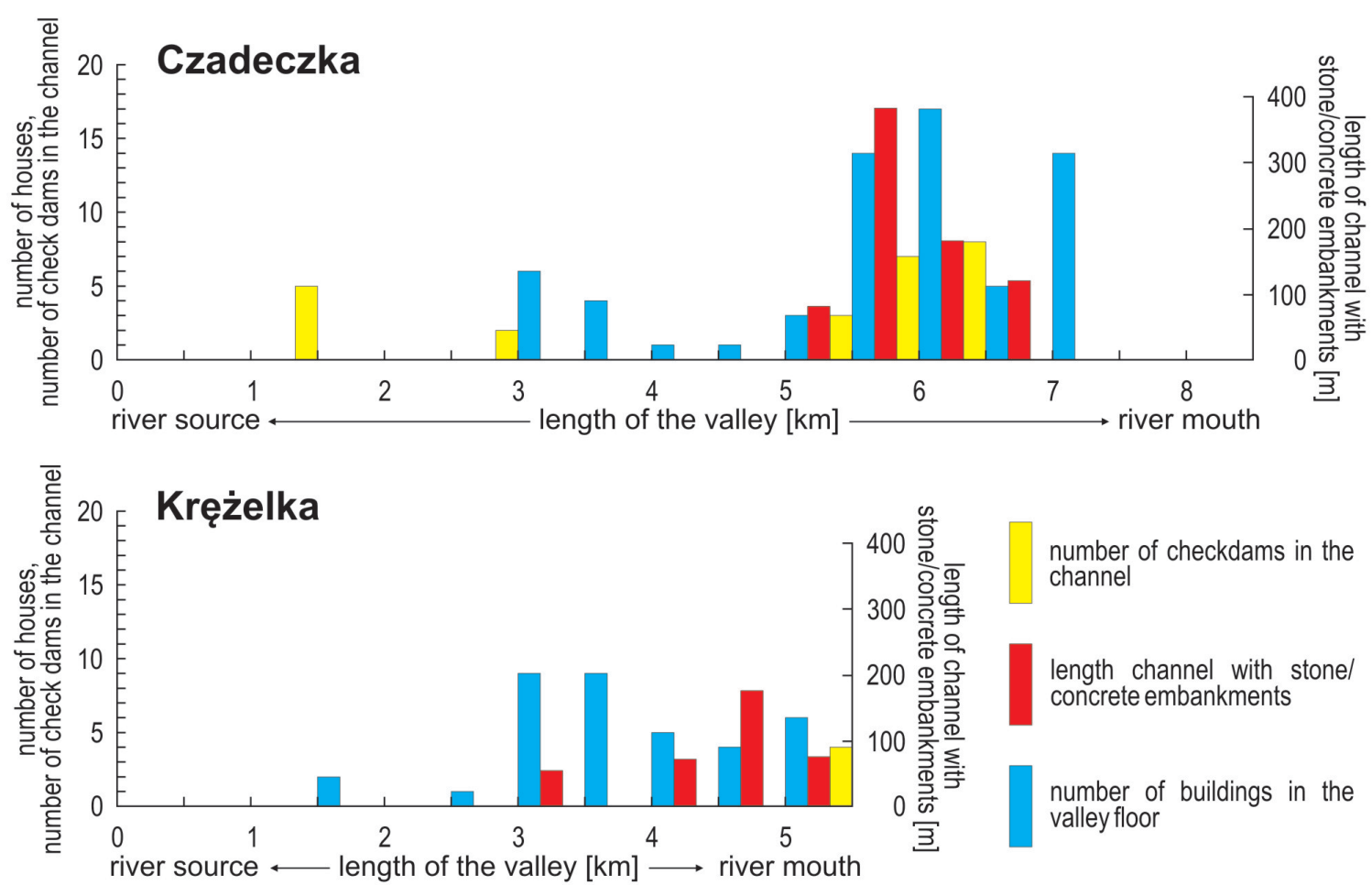

Fig. 2. Comparison of the number of buildings on the valley floors and the occurrence of concrete or stone embankments and check dams in the channels of the Czadeczka and Krężelka rivers divided into 500-m long sections (based on a field survey conducted in 2014).

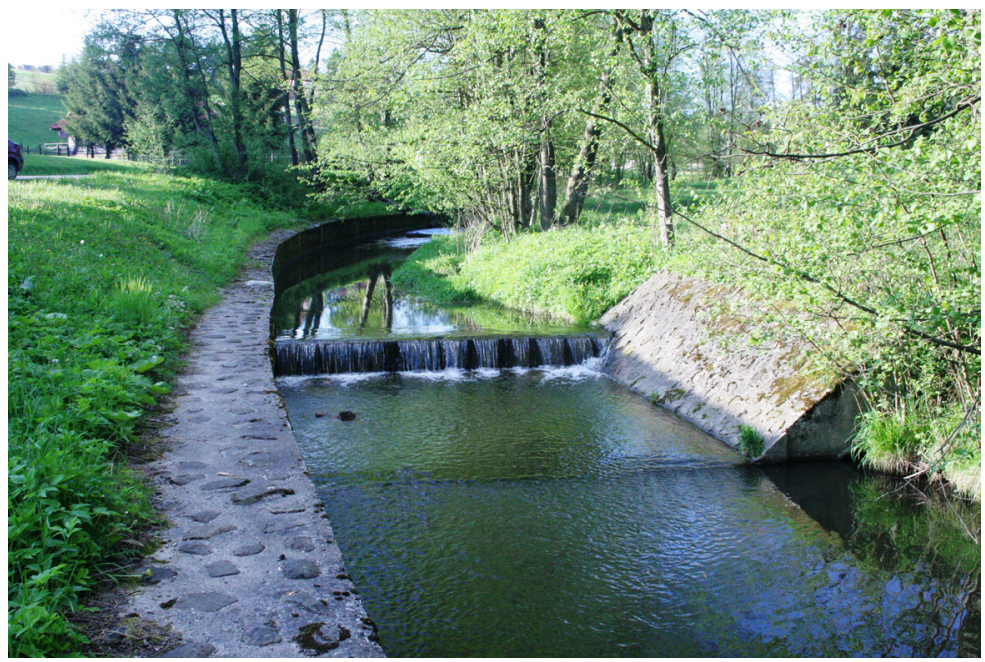

Fig. 3. Concrete embankment and concrete check dam in the Czadeczka channel.

Local inhabitants bring pressure to bear on the local authorities to regulate both rivers. First, channel banks are reinforced with stone blocks or concrete to prevent lateral erosion and then channelised. Next, after the channel is straightened, heavy bed erosion occurs. Thus, the channel bed is concreted over and check dams are constructed against the incision.

The issuance of construction permits on the valley floors and further river regulation result in numerous adverse consequences. Rivers lose their natural reaches, channels, whereas valleys lose their natural, ecological, and aesthetic advantages [Lenar-Matyas et al. 2010]. People who settle in valley floors and areas close to rivers are constantly endangered by fluvial erosion and overbank flows during flooding, despite the regulation efforts described above. Local governments and other authorities responsible for the situation in river valleys need to bear the costs of river regulation, anti-erosion and flood-protection actions, as well as the costs of rescue and financial aid in case of floods [Kundzewicz et al. 2010]. All these actions are irrational because if the described tendency of settlement on the valley floors continues, soon the need to restore currently regulated rivers will arise. At the same time, there are guidelines for rational and efficient development of valley floors of mountain rivers. At the order of 


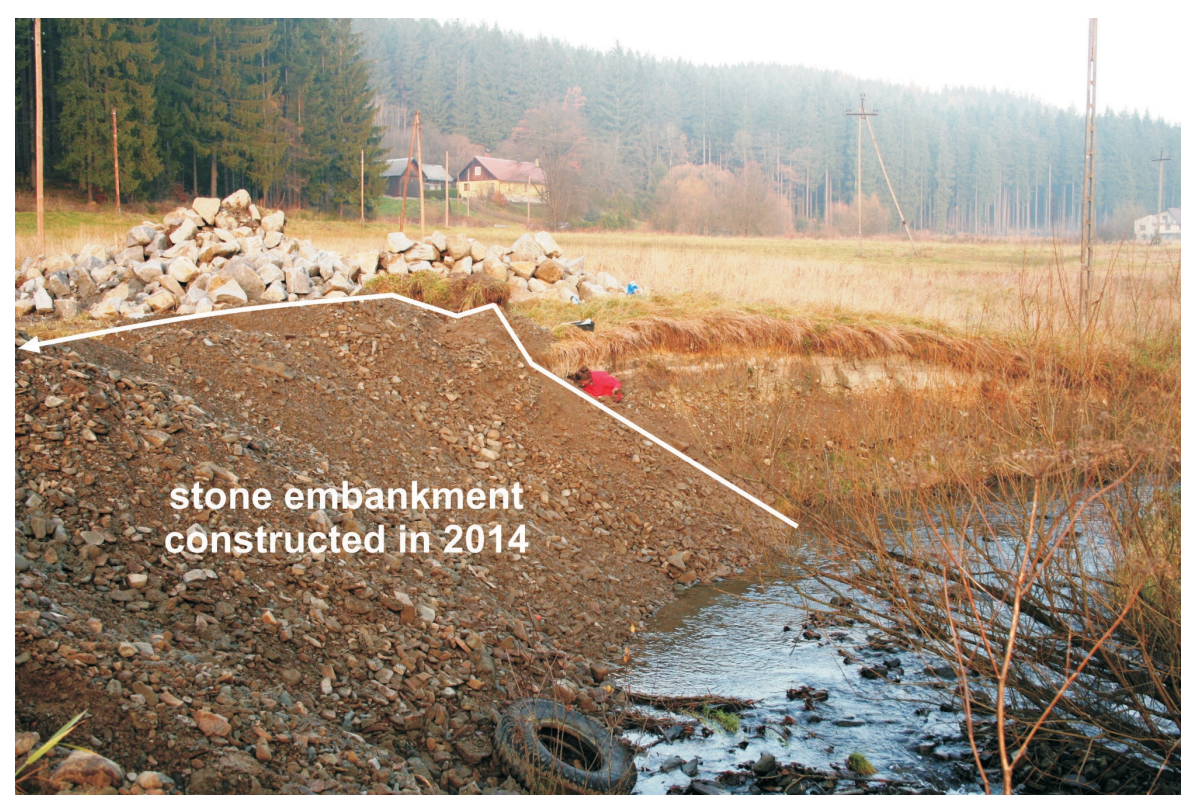

Fig. 4. Ongoing construction of stone embankment in the Krężelka channel in 2014.

Polish Ministry of Environment, the following work was published in 2005: 'Good-practice manual of sustainable maintenance of mountain streams and rivers in southern Poland' [Bojarski et al. 2005]. The study describes adverse natural phenomena related to development of hydraulic structures in river channels along with recommendations for certain actions leading to the preservation of spatial order within valley floors. For instance, there is an option to widen the undeveloped zones along channels instead of erecting anti-erosion constructions and embankments in the channels. Corridors of free channel migration devoid of buildings are then created. Possible flood-protection structures are then located outside of the corridor. It should be considered that massive concrete structures constructed in the channels lead to irreversible and irreparable changes in the character and the condition of rivers [Lenar-Matyas et al. 2010]. The results of regulation works are long term. The ensuing changes in the channel pattern are not final because one regulated section of a channel influences the adjacent channel sections, both downstream and upstream. Bed erosion (incision) of channels is also an indirect effect of regulation. Increased velocity of water flow caused by regulation disturbs the balance between a river's ability to transport debris and the sediment load in reality transported by a channel, which leads to an abrupt deepening of the channel [Wyżga 1991, 2008].

Regulation, in particular channelisation when concrete bottoms and banks are formed, isolates water from permeable bedrock and causes irreversible changes in water circulation [Froehlich 1990]. Channel deepening also results in lowering of groundwater table in valley floors and in exposing, eroding, and undercutting man-made hydraulic structures or piers of bridges [Wyżga 1991, 2008]. Channel regulation also speeds up water transfer in drainage basins, which is unfavourable for both ecosystem protection and economy. It is a phenomenon completely opposite to the solutions suggested by ecohydrology [Zalewski 2011].
Local governments are responsible for outlining flood area and informing investors on flood hazard in the investment areas. However, they usually fail to do that. The problem was described in a report published by the Polish Supreme Audit Office (Najwyższa Izba Kontroli) after inspections concerning the floodcontrol policy carried out in the administrative districts. Currently, recommendations included in the report are being implemented [Najwyższa Izba Kontroli 2009].

\section{CONCLUSIONS}

Valley floors of the Czadeczka and Krężelka rivers were a subject of gradual building development during the last decades. In areas where buildings were erected, natural river reaches were regulated due to the fear of floods and ongoing lateral erosion. River banks were reinforced with rock or concrete embankments. In the channel bottoms, check dams were constructed. In effect, rivers lost their natural character. The actions mentioned above are performed even now despite the fact that they lack justification. Issuance of construction permits and investment on mountain valley floors, among others on floodplains, puts people at risk of material losses in case a flood occurs. Building development on valley floors increases potential losses caused by flooding and lateral erosion. As a consequence, river channels flowing close to houses are regulated, but these actions still do not provide efficient protection. In addition, regulation causes irreversible changes in the valley ecosystems. Rivers gradually lose their natural character, mountain valleys lose their aesthetic advantages. The practice is harmful in terms of economy (costs of floods in the insufficiently protected areas), society (losing property due to flood, permanent sense of threat), ecology (disturbed natural river balance, disturbed ecosystems) and aesthetics (natural river reaches are transformed into channelised, straight, concrete channels). 


\section{REFERENCES}

BOJARSKI A., JELEŃSKI J., JELONEK M., LITEWKA T., WYŻGA B., ZALEWSKI J. 2005. Zasady dobrej praktyki w utrzymaniu rzek i potoków górskich. Ministerstwo Środowiska, Warszawa.

BUCAŁA A, RADECKI-PAWLIK A. 2011. Wpływ regulacji technicznej na zmiany morfologii górskiego potoku: potok Jamne, Gorce. Acta Scientiarum Polonorum 10, 1: 3-16.

FROEHLICH W. 1990. Racjonalna zabudowa koryt potoków pod kątem zabezpieczenia przeci.wpowodziowego i przeciwerozyjnego. Problemy Zagospodarowanie Ziem Górskich 30: 49-69.

KLIMEK K. 1983. Erozja wgłębna dopływów Wisły na Przedpolu Karpat (Vertical erosion of Vistula tributaries on the Carpathian foreland) (Polish, with English Abstr.). [In:] Kajak Z. (ed.) Ekologiczne podstawy zagospodarowania Wisły i jej dorzecza. PWN, Warszawa Łódź: 97-108

KLIMEK K. 1987. Man's impact on fluvial processes in the Polish Western Carpathians. Geografiska Annaler 74A: 123-131.

KONDRACKI J. 2000. Geografia regionalna Polski. Wydawnictwo Naukowe PWN, Warszawa

KORPAK, J. 2007. The influence of river training on mountain channel changes (Polish Carpathian Mountains) Geomorphology, 92(3): 166-181.

KRZEMIEŃ K. 1981. Zmienność subsystemu korytowego Czarnego Dunajca (The changeability of the Czarny Dunajec channel subsystem). Zeszyty Naukowe Uniwersytetu Jagiellońskiego, Prace Geograficzne 53: 123-137 (in Polish, with English summary).

KRZYK P. 2010. Wybrane aspekty zagospodarowania karpackich dolin rzecznych. Architektura Krajobrazu 1: 11-17.

KUNDZEWICZ, Z.W., ZALEWSKI, M., KĘDZIORA, A., PIERZGALSKI, E. 2010. Zagrożenia związane z wodą Raport o zagrożeniach - próba diagnozy. Rozprawy Komitetu Badań nad Zagrożeniami przy Prezydium PAN 4: 87-96.

LENAR-MATYAS A., LAPUSZEK M., LAFONT M., POULARD

C. 2010. Możliwości rewitalizacji koryt rzek i potoków w warunkach ich zróżnicowanego zagospodarowania. Infrastruktura i Ekologia Terenów Wiejskich 9: 17-27.
NACHLIK E. (ed.) 2004. Identyfikacja i ocena skutków antropogenicznych oddziaływań na zasoby wodne dla wskazania części wód zagrożonych nie osiągnięciem celów środowiskowych. Politechnika Krakowska, Kraków.

NAJWYŻSZA IZBA KONTROLI 2009. Informacja o wynikach kontroli. Ochrona przeciwpowodziowa w województwie małopolskim i świętokrzyskim. NIK, Kraków: 25-27.

WOHL E. 2006. Human impacts to mountain streams Geomorphology, 79(3), 217-248.

WOLMAN M.G. 1967. A cycle of sedimentation and erosion in urban river channels. Geografiska Annaler 49A: 385-395.

WYŻGA B. 1991. Present-day downcutting of the Raba river channel (Western Carpathians, Poland) and its environmental effects. Catena 18, 6: 551-566.

WYŻGA B. 2008. Wcinanie się rzek polskich Karpat w ciągu XX wieku. [In:] B. Wyżga (ed.) Stan środowiska rzek południowej Polski i możliwość jego poprawy - wybrane aspekty. Instytut Ochrony Przyrody PAN, Kraków: 7-39.

WYŻGA, B. 2008. A review on channel incision in the Polish Carpathian rivers during the 20th century. [In:] Habersack, H., Piégay, H., Rinaldi, M. (ed.) Gravel-bed Rivers VI From Process Understanding to River Restoration. Elsevier, Amsterdam: 525-556

ZALEWSKI M. 2011. Ecohydrology for implementation of the EU water framework directive. Water Management 164, 8: 375-385.

ZAWIEJSKA J., KRZEMIEŃ K. 2004. Human impact on the dynamics of the upper Dunajec River channel: a case study. Geograficky Časopis 56: 111-124

ŻBIKOWSKI A., ŻELAZO J. 1993. Ochrona środowiska w budownictwie wodnym, materiały informacyjne. Agencja Wydawnicza „Falstaff”, Warszawa.

ŻELAZO J. 2006. Renaturyzacja rzek i dolin. Zeszyty Naukowe Infrastruktura i Ekologia Terenów Wiejskich, PAN 4: 11-31. 